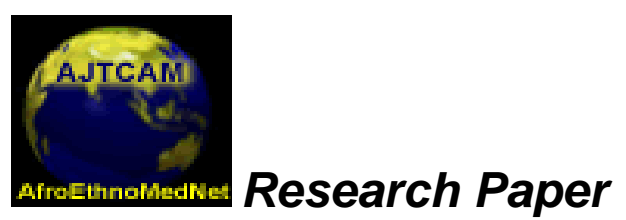
Afr. J. Traditional, Complementary and Alternative Medicines
www.africanethnomedicines.net

ISSN 0189-6016@2008

\title{
BEHAVIOURAL EFFECTS OF THE METHANOLIC ROOT BARK EXTRACT OF SECURINEGA VIROSA IN RODENTS
}

\author{
${ }^{* 1}$ Magaji, M.G., ${ }^{1}$ Anuka, J.A., ${ }^{1}$ Abdu-Aguye, I., ${ }^{2}$ Yaro, A.H and ${ }^{3}$ Hussaini, I. M. \\ ${ }^{1}$ Department of Pharmacology and Clinical Pharmacy, Ahmadu Bello University, Zaria, Nigeria \\ ${ }^{2}$ Department of Pharmacology, Faculty of Medicine, Bayero University, Kano, Nigeria \\ ${ }^{3}$ Department of Pathology (Neuropathology), University of Virginia, 415 Lane Road, MR5 Bldg, \\ Charlottesville, Virginia, 22908 \\ *E-mail: magmas1@yahoo.com Tel.08034685849
}

\begin{abstract}
Securinega virosa is used traditionally as sedative in children and in mental illnesses. In this study, the behavioral effects of methanolic root bark extract of $S$. virosa were investigated in mice. The results revealed that the extract significantly $(\mathrm{P}<0.05)$ and dose-dependently reduced the onset and prolonged the duration of sleep. The extract significantly $(\mathrm{P}<0.05)$ decreased exploratory activity and reduced the rate of apomorphine-induced stereotyped climbing at the doses tested $(6.25-25 \mathrm{mg} / \mathrm{kg})$. It also produced a significant and dose-dependent motor coordination deficit in mice at the doses tested $(\mathrm{P}<0.01)$. The intraperitoneal median lethal dose in mice was $774.6 \mathrm{mg} / \mathrm{kg}$ while the preliminary phytochemical screening revealed the presence of alkaloids, tannins, saponins and flavonoids. These results suggest that methanolic root bark extract of $S$. virosa contains biologically active principles that are sedative in nature and lend pharmacological credence to the ethnomedical use of the plant.
\end{abstract}

Key words: Behaviour, Securinega virosa, motor coordination, exploratory activity, stereotyped climbing.

\section{Introduction}

One important area in which herbal medicines enjoy high patronage worldwide is in the management of psychiatric disorders. The herbs are used in combination with other rituals for the treatment of mentally sick individuals. A good number of natural product scientists believe that the initial selection of plants with diverse application in traditional medicine might be encouraged by their easily noticeable CNS effects (Etkin, 1988).

Securinega virosa is one of the great African medicinal plants described as a true "cure all", of which all parts are used as remedies, particularly the root. It is widely distributed throughout tropical Africa, India, Malaya, China and Australia (Dalziel, 1936). In Nigeria, it is found in virtually all parts of the country (Neuwinger, 1996). In many parts of Africa including the north Eastern Nigeria, the root and leafy twig decoctions are used for the treatment of epilepsy. The plant is said to have a hallucinogenic effect (Neuwinger, 1996) and the decoction of the root with other plant is used in Northern Nigeria for the treatment of mental illness.

To the best of our knowledge, there are scanty reports in literature on the behavioural effects of $S$. virosa, so we decided to study the behavioural effects of the plant on diazepam-induced sleep, hole-board test, apomorphine-induced strereotyped climbing behaviour and beam walking assay in mice.

\section{Materials and Methods}

Fresh root parts of S. virosa were collected from a secondary forest in Basawa town, Sabon-Gari Local Government area of Kaduna State, Nigeria. The collection was authenticated by Malam Musa and Umar Galla of the Herbarium Section in the Department of Biological Sciences, Ahmadu Bello University (ABU), Zaria. A voucher 
specimen (NO 918) was deposited at the herbarium for future reference. The root was cleaned and the bark removed. The root bark was air dried under shade until a constant weight was obtained. It was then size-reduced into coarse powder with a pestle and mortar. $100 \mathrm{~g}$ of the powered root bark was extracted with $500 \mathrm{ml}$ methanol for $72 \mathrm{hrs}$ using Soxhlet extraction apparatus. The solvent was evaporated to give an average yield of $12.63 \% \mathrm{w} / \mathrm{w}$. The extract was then stored in a desiccator. Phytochemical screening was done in accordance with the standard protocol as described by Trease and Evans (1983).

\section{Experimental animals}

Swiss albino mice of either sex $(20-30 \mathrm{~g})$ were obtained from the animal house facilities of the Department of Pharmacology and Clinical Pharmacy, ABU, Zaria. Day old white Rangers cockerels were obtained from the National Animal Production Research Institute (NAPRI), Shika, Kaduna, Nigeria. The mice maintained on Excel feeds, Ilorin and water ad libitum, were housed in polypropylene cages at room temperature throughout the study. All experimental protocols were approved by the University animal ethics committee. The experiments were conducted in quiet laboratory between hrs of $900 \mathrm{~h}$ to $1600 \mathrm{~h}$.

\section{Acute Toxicity studies $\left(\mathbf{L D}_{50}\right)$}

$\mathrm{LD}_{50}$ determination was conducted using the method of Lorke (1983) using the intraperitoneal (i.p.)route in mice. Briefly; the method was done into two phases. In the initial phase, 3 groups of three mice each were treated with the methanol root bark extract of the plant at doses of 10,100 and $1000 \mathrm{mg} / \mathrm{kg}$ body weight i.p. and observed for signs of toxicity and death for $24 \mathrm{hrs}$. In the second phase, 4 groups each containing one mouse was injected with four more specific doses of the extract. The $\mathrm{LD}_{50}$ value was determined by calculating the geometric mean of the lowest dose that caused death and the highest dose for which the animal survived (0/1 and 1/1).

\section{Diazepam-induced sleep in mice}

The method described by Beretz et al. (1978) and modified by Rakotonirina et al. (2001) was adopted in this study. 24 Swiss albino mice of either sex were randomly divided into four groups each containing 6 mice. The first group served as control and was given normal saline equivalent to the vehicle given with the extract i.p. The second, third and fourth groups were pre-treated with $6.25,12.5$ and $25 \mathrm{mg}$ extract per kg body weight, i.p. $30 \mathrm{mins}$ post-treatment, the mice were administered diazepam at a dose of $30 \mathrm{mg} / \mathrm{kg}$ body weight, i.p. The mice were placed individually in cages. The onset and the duration of sleep were determined for each animal. Loss of rightening reflex was considered as the criterion for sleep (Rolland et al., 1991) while the interval between the loss and the recovery of straightening was regarded as the duration of sleep (Fujimori, 1965).

\section{Test for Exploratory activity in mice}

The method for the hole-board test in mice was similar to those described previously (File, 1973). The apparatus used was a white painted wooden board $(60 \mathrm{~cm} \times 30 \mathrm{~cm})$ with 16 evenly spaced holes $(1 \mathrm{~cm}$ diameter $\mathrm{x}$ $2 \mathrm{~cm}$ depth). 30 mice were randomly divided into 5 groups each containing 6 mice. The mice in the first group served as control and received normal saline equivalent to the vehicle given with the extract. The mice in the second, third and fourth will received $6.25,12.5$ and 25 extract per kg body weight, respectively while the mice in the fifth group received $1 \mathrm{mg}$ diazepam per kg body weight. All drugs and extract were administered intraperitoneally. 30 minutes post- treatment, each mouse was placed at a corner of the board and the number head dips on the hole was counted using a tally counter during 5minutes (Wolfman et al., 1994).

\section{Apomorphine-induced stereotyped climbing in mice}

Adult male Swiss albino mice were randomly divided into five groups each containing six mice. The first group received normal saline equivalent to the vehicle given with the extract i.p. The second, third and the fourth groups received the extract at doses of $6.25,12.5$ and $25.0 \mathrm{mg} / \mathrm{kg}$ body weight, respectively, i.p. 30 mins after treatment; all mice were treated with apomorphine $(30 \mathrm{mg} / \mathrm{kg}$ body weight, subcutaneously). Each mouse was placed singly in a wire mesh stick cage and the climbing behaviour was observed at 10,20 and 30 mins interval after apomorphine administration and scored as follows: 
$0=$ four paws on the floor; 1 = fore feet holding the vertical bars; 2 = four feet holding the vertical bars. The ability of a drug to antagonize apomorphine-induced stereotyped climbing behaviour in the mouse has been correlated with neuroleptic potential (Prostais et al., 1976, Costall et al., 1978).

\section{The mouse beam walking assay for motor in-coordination}

The method previously described by Stanley et al., (2005) was adopted for this study. Adult male Swiss albino mice weighing $20-30 \mathrm{~g}$ were trained to walk from a start platform along a ruler $(80 \mathrm{~cm}$ long, $3 \mathrm{~cm}$ wide) elevated $30 \mathrm{~cm}$ above the bench by metal support to a goal box. Three trials were performed for each mouse, and were designed such that the mouse tested would be aware that there was a goal box that could be reached. The mice that successfully walked along the ruler were randomly grouped into five groups each containing six mice. The first group received normal saline equivalent to the vehicle given with the extract, i.p. The second, third and the fourth groups received the extract at doses of $6.25,12.5$ and $25.0 \mathrm{mg} / \mathrm{kg}$ body weight respectively, i.p. The fifth group received diazepam $(1 \mathrm{mg} / \mathrm{kg}$ body weight, i.p.). The beam was made of wood, $8 \mathrm{~mm}$ in diameter, $60 \mathrm{~cm}$ long and elevated $30 \mathrm{~cm}$ above the bench by metal support. 30 mins post- treatment, each mouse was placed on the beam at one end and allowed to walk to the goal box. Mice that fell were returned to the position they fell from, with a maximum time of 60s allowed on beam. The number of foot slips (one or both hind limb slipping from the beam) was recorded with the aid of a tally counter. The number of foot slip is a measure of motor coordination deficit (Stanley et al., 2005).

\section{Statistical analysis}

The results were analyzed for statistical significance using one-way ANOVA followed by Dunnet's test. A $P$ value $<0.05$ was considered significant.

\section{Results}

The preliminary phytochemical screening of the methanolic root bark extract of $S$. virosa revealed the presence of saponins, tannins, glycosides, alkaloids and steroids.

The intraperitoneal median $\mathrm{LD}_{50}$ value of the extract in mice was found to be $774.6 \mathrm{mg} / \mathrm{kg}$ body weight.

The extract significantly $(\mathrm{p}<0.05)$ decreased the onset of diazepam induced sleep at all the dose levels tested $(6.25,12.5$ and $25 \mathrm{mg} / \mathrm{kg})$. It significantly $(\mathrm{p}<0.001)$ and dose- dependently prolonged the duration of sleep induced by diazepam (Figure 1).

The extract at the doses tested $(6.25,12.5$, and $25 \mathrm{mg} / \mathrm{kg})$ caused significant $(\mathrm{p}<0.01)$ decrease in the number of head dips in the hole-board experiment (Figure 2). Similarly, Diazepam $(1 \mathrm{mg} / \mathrm{kg})$ caused a significant decrease in exploratory activity.

The extract significantly $(\mathrm{p}<0.01)$ inhibited apomorphine-induced stereotyped climbing behaviour at all the three doses tested, thirty mins post apomorphine administration. However, the attenuation of the climbing behaviour was not dose-dependent (Figure 3). The standard drug, haloperidol significantly attenuated the climbing behaviour in mice.

The extract significantly and dose dependently produced motor coordination deficit at the doses tested $(6.25,12.5$ and $25.0 \mathrm{mg} / \mathrm{kg})$. The standard drug, diazepam, significantly impaired motor coordination $(\mathrm{p}<0.01)$ at the dose of $1 \mathrm{mg} / \mathrm{kg}$ (Figur 4).

\section{Discussion}

The extract significantly $(P<0.05)$ and dose-dependently reduced the onset and prolonged the duration of sleep induced by diazepam. By potentiating the diazepam-induced sleep, the extract seems to possess sleep inducing properties (Guillemain and Tetau, 1980; Rakotonirina et al., 2001). Sedative-hypnotic agents act to increase GABAmediated synaptic inhibition either by directly activating GABA receptors or, more usually, by enhancing the action of GABA on $\mathrm{GABA}_{\mathrm{A}}$ receptors. Benzodiazepines and barbiturates are examples of widely used therapeutic agents that act as positive allosteric modulators at $\mathrm{GABA}_{\mathrm{A}}$ receptors (Johnston, 2005). The ability of the extract to 


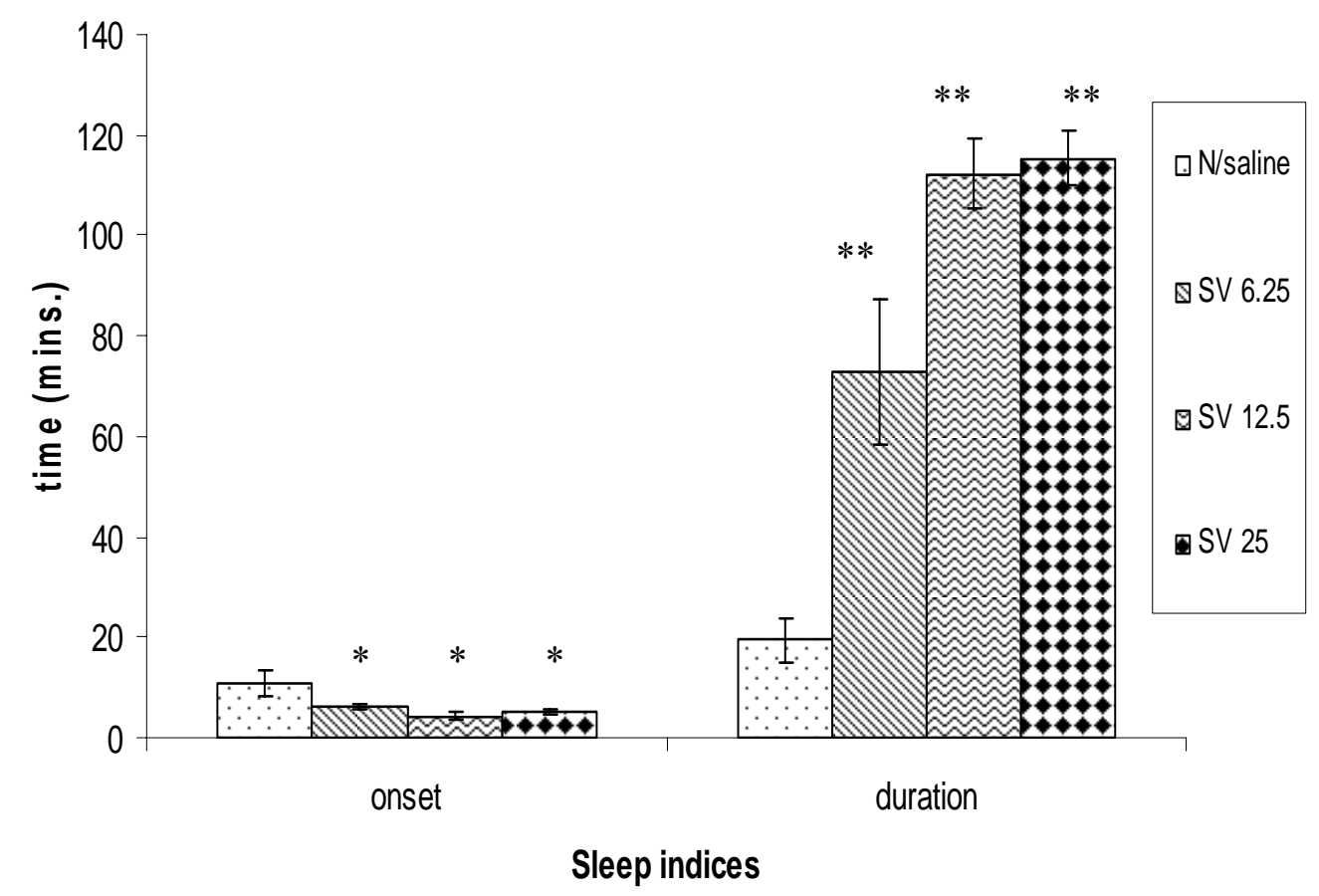

Figure 1: The effect of Methanolic root bark Extract of S.virosa on Diazepam-induced sleep in mice; *(P<0.05) and $* *(\mathrm{P}<0.001), \mathrm{n}=6$

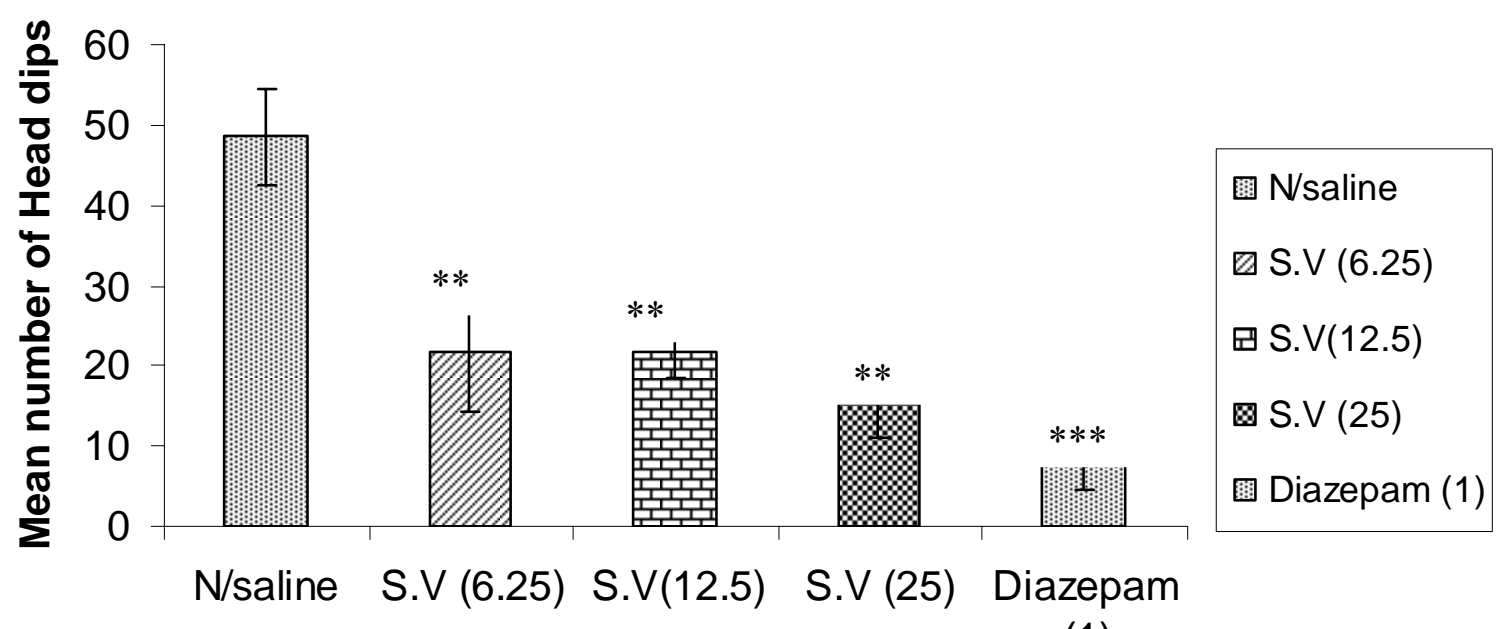

(1)

\section{Treatment $(\mathrm{mg} / \mathrm{kg})$}

Figure 2: The effect of Methanolic root bark Extract of S.virosa on Exploratory activity in mice; $* *(\mathrm{P}<0.01)$ and $* * *(\mathrm{P}<0.001), \mathrm{n}=6$ 


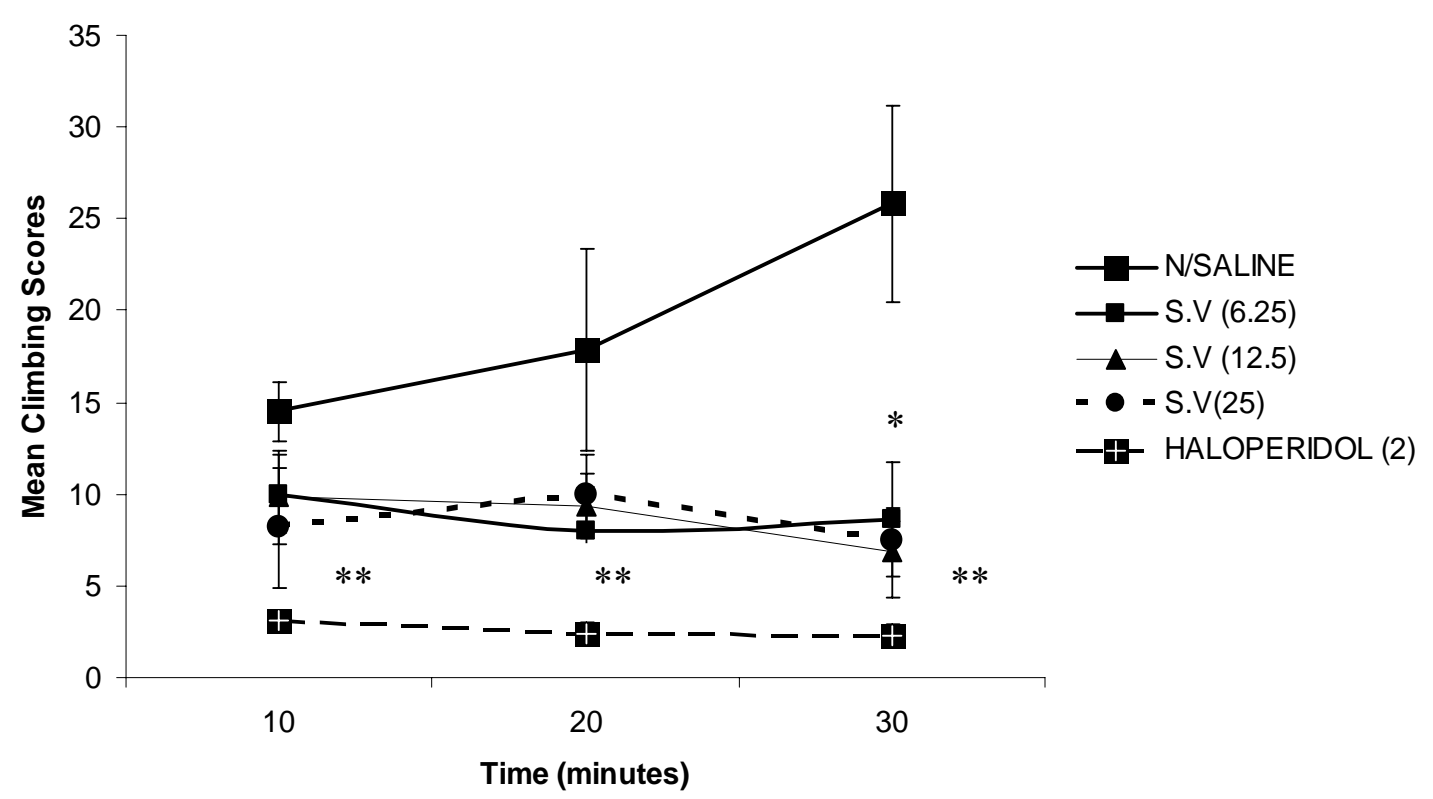

Figure 3: The effect of Methanolic root bark Extract of S.virosa on apomorphine-induced stereotyped climbing behaviour in mice $*(p<0.05)$, and $* *(p<0.001) n=6$

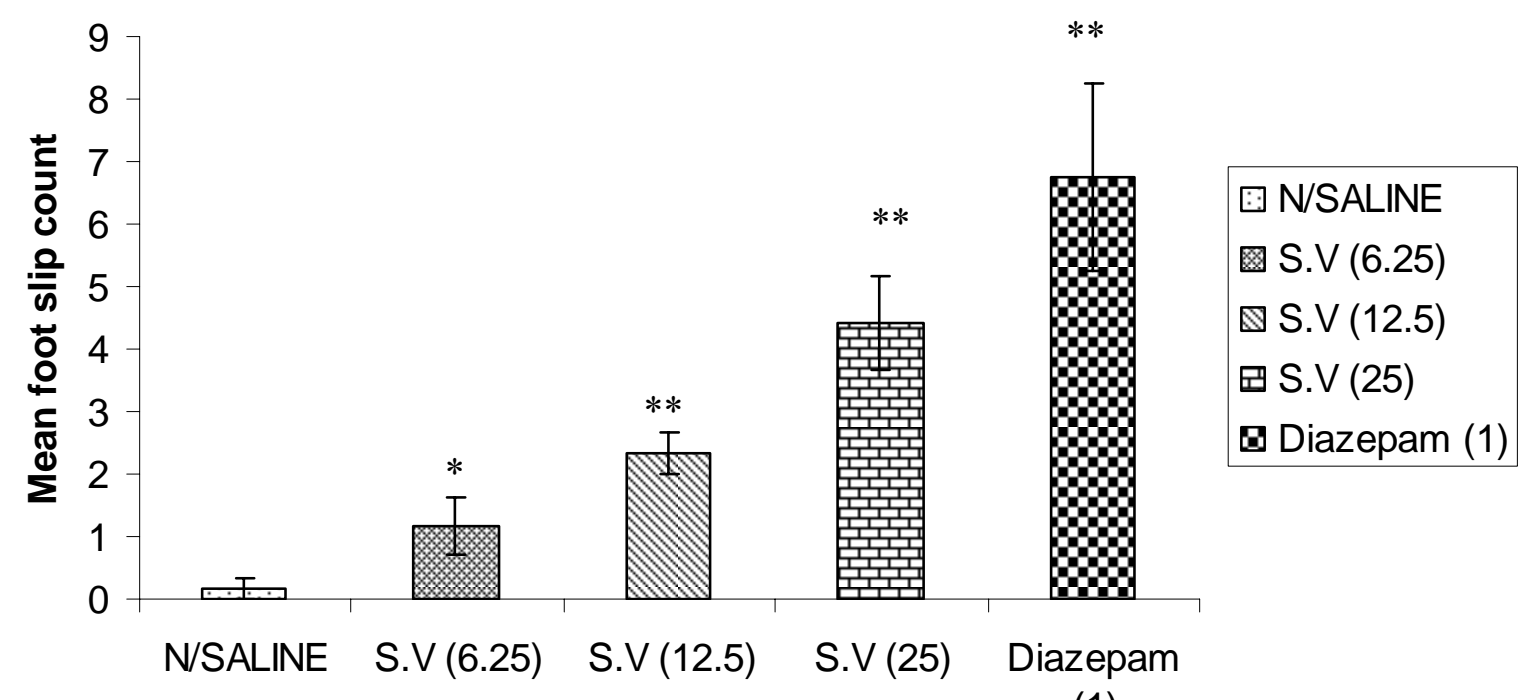

(1)

Treatment (mg/kg)

Figure 4: The effect of Methanolic root bark Extract of S.virosa and diazepam on motor coordination in mice. $*(p<0.05),{ }^{* *}(\mathrm{p}<0.01)$, and $* * *(p<0.001)$ $\mathrm{n}=6$ 
potentiate the sedative property of diazepam suggests that it may possibly act by interacting with GABA-mediated synaptic transmission.

The extract significantly produces a decrease in the exploratory behaviour pattern as shown in the head dip result. According to File and Wardill (1975), the hole-board experiment is a measure of exploratory behaviour in animals. A decrease in this parameter reveals a sedative behaviour (File and Pellow, 1985) and it has been accepted as a parameter for the evaluation of anxiety conditions in animals (Crawley, 1985). Decrease in exploratory activity in mice as demonstrated by reduction in head dip is a measure of CNS depressant activity (Adzu, 2002). The decrease in exploratory behaviour further supports the neurosedative property of the extract and its possible application in anxiety condition (Amos et al., 2001).

The extract significantly $(\mathrm{p}<0.05)$ and dose-dependently increased the number of foot slips made by the mice. The number of foot slips made has been found to be a sensitive measure at determining Benzodiazepineinduced motor coordination deficits and is a good predicator of doses producing clinical sedation (Stanley et al., 2005). By increasing the number of foot slips made by rodents, the extract seems to possess a sedative property.

The ability of a drug to antagonize apomorphine-induced climbing behaviour in the mouse has been correlated with neuroleptic activity ( Prostais et al., 1976; Costall et al., 1978). Inhibition of apomorphine-induced climbing in mouse is suggestive of $\mathrm{D}_{1}$ and $\mathrm{D}_{2}$ receptor blockade (Moore and Axton, 1988). The ability of the extract to antagonize apomorphine-induced climbing behaviour supports the hypotheses of central activity which might be related to anti-dopaminergic actions on the limbic system as suggested by Anca et al., (1993) and Morais et al., (1998). It has been reported that the saponins show a potent sedative activity when tested in similar models (Dubois et al., 1986). Alkaloids are the most important secondary metabolites in many plants that are held responsible for their sedative and anxiolytic action (Elizabetsky and Costa-Campos, 2006). The flavonoid, hispidulin has been reported to act as a positive allosteric modulator across a range of $\mathrm{GABA}_{\mathrm{A}}$ receptor subtypes (Kavvadias et al., 2004). It is therefore plausible to suggest that the sedative activity of extract may be due to the presence of alkaloid, saponins and flavonoids among other phytochemical constituents which have been shown to be present in the extract.

This study, therefore, suggests that the methanolic root bark extract of $S$. virosa possesses central sedative property and lend pharmacological credence to traditional use of the plant as sedative in children and in the management of mental illnesses. Further work is going on in our laboratory to isolate the compound responsible for the observed sedative effect of the root bark extract of the plant.

\section{References}

1. Adzu, S., Amos, S., Dzarma, C.W. and Gamaniel, K. (2002). Effect of Zizypus spinchristi wild aqueous extract on the central nervous system in mice. J. Ethnopharmacol., 79:13-16

2. Amos, S., Kolawole, E., Akah, P., Wambebe, C. and Gamaniel, K. (2001). Behavioural effect of the aqueous extract of Guiera senegalensis in mice and rats. Phytomedicine. 8 (5): 356-361

3. Anca, J.M., Lamela, M. and Calleja, J.M. (1993). Activity on the central nervous system of Himanthalia elongata. Planta medica, 5:218-220.

4. Beretz, A., Haag-Berrurie, M and Anton, R. (1978). Choix de méthodes pharmacologiques pour l'étude des activités de l'aubépine. Plantes médicinales et phytothérapie 4: 305-314.

5. Costall, B. and Naylor, R.J. (1974). On catalepsy and catatonia and the predictability of the cataleptic test for neuroleptics activity. Psychopharmacol. (Berlin), 34:233-241.

6. Crawley, J.N (1985).Exploratory behavior models of anxiety in mice. Neuroscience behavioral reviews, 9:3744.

7. Dalziel, J. M. (1936). The useful plants of West Tropical Africa Watmonghs, Idle, London. pp. 354-355.

8. Elizabetsky, E. and Costa-Campos, L. (2006). The alkaloid alstonine: a review of its pharmacological properties. eCAM, 3:39-48

9. Etkin, N.L. (1988). Ethnopharmacology: Behavioural approaches in the anthropological study of indigenous medicines. Annual Review Anthropol. 17:23-42

10. Dubois, M.A., Ilyas, M. and Wagnar, H. (1986). Cussonoides A and B, two Triterpenes-saponins from Cussonia barteri. Planta Medica, 56: 80-83

11. File, S. and Pellow, S. (1985).The effect of triazolobenzodiazepines in two animal tests of anxiety and on the hole-board. Bri. J. Pharmacol., 86:729-735.

12. File, S.E. (1973). Effects of Chlorpromazine on exploration and habitation in the rat. Bri. J. Pharmacol.. 49: 303-31 
13. Files, S.E and Wardill, A.G (1975). Validity of head dipping as a measure of explorating a modified hole-board. Psychopharmacologia, 44:53-59.

14. Fujimori, H. (1965) Potentiation of barbital hypnosis as an evaluation method of central nervous system depressant. Psychopharmacol., 7: 374-397.

15. Guillemain, J.and Tetau, M. (1980). Contribution à l'étude d'un "tranquillisant végétal" Tilia tomentosa Bourgeons. Cahiers de Biothérapie, 68: 1-8.

16. Johnston, G.A.R. (2005). GABA $A_{A}$ Receptor Channel Pharmacology. Current Pharmaceutical Design, 11: 18671885

17. Kavvadias, D., Sand, P., Youdim, K.A., Rice-Evans, C., Baur, R., Siegel, E., Rausch, W.F., Riederer, P. and Schreier, P. (2004). The flavone hispidulin, abenzodiazepine receptor ligand with positive allosteric properties, traverses the blood-brain barrier and exhibits anti-convulsant effects. Bri. J. Pharmacol., 142: 811-820

18. Lorke, D.D. (1983). A new approach to acute toxicity testing. Arch Toxicol., 54:275-283.

19. Moore, N.A. and Axton, M.S. (1988). Production of climbing behaviour in mice requires both D1 and D2 receptors activation. Psychopharmacol. 94:261-269.

20. Morais, L. C. S. L., Barba-filho, J. M. and Almeida, R. N. (1998). Central depressant effects of reticuline extracted from Ocotea duckei in rats and mice. J. Ethnopharmacol., 62:57-61

21. Neuwinger J.D (translated from the German by Porter, A.) (1996). African ethnobotany-poisons and drugs. Chapman and Hall, Weinheim pp.495-499.

22. Prostais, P.,Costentin, J. and Schwartz, J.C. (1976). Climbing behaviour induced by apomorphine in mice: A simple test for the study of dopamine receptors in the striatum.Psychopharmacol., 50:1-6

23. Rakotonirina, S.V.,Ngo Bum, E., Rakotonirina, A and Bopelet, M.(2001). Sedative properties of the decoction of the rhizome of Cyperus articularis. Fitoterapia 72:22-29.

24. Rolland, A., Fleurentain, J., Lanhers, M., Younos C., Misslin, R., Morier, F. (1991) Behavioural effects of American traditional plant. Eschscholzia California: Sedative and anxiolytic properties: Planta medica, 57:212216.

25. Stanley, J.L., Lincoln, R.J.,Brown, T.A., McDonald, L.M., Dawson, G.R. and Reynolds, D.S.(2005) The mouse beam walking assay offers more sensitivity over the rotarod in determining motor coordination deficits induced by benzodiazepines. Psychopharmacol., 19 (3): 221-227.

26. Trease, G. E., Evans, M.C. (1983) Textbook of Pharmacology $12^{\text {th }}$ ed. Balliere Tindall, London. pp. 322-383.

27. Wolfman, C., Viola, H., Paladini, A.C., Dajas, D., Medina, J.H. (1994). Possible anxiolytic effects of chrysin, a central benzodiazepine receptor ligand isolated from Passiflora coeruiea. Pharmacol. Biochem. Behav. 47:1-4 